\title{
State of the World in Nursing Research
}

\author{
Hester C. Klopper ${ }^{1 *}$, Marie Claire Gasanganwa ${ }^{2}$ \\ ${ }^{1}$ North West University, South Africa and North-West University (Potchefstroom campus), South Africa \\ ${ }^{2}$ University of Rwanda, College of Medicine and Health Sciences, Rwanda
}

\begin{abstract}
The purpose of this article is to provide a global overview of the status of nursing research, showing the vast need for the increase in doctorally prepared nurses. There are several trends that influence nursing research, education, and practice and will continue to do so over the next decade. The paper discusses four of these trends: technology, workforce issues, inter-professional education and practice, and the need for more $\mathrm{PhD}$ prepared nurses. Finally, the paper concludes with some recommendations to build capacity in nursing research in Africa. After the paper was delivered at the global nursing conference in Kigali, it was followed by a response from Rwanda, to contextualize the paper in the local setting. This response is integrated into this paper.
\end{abstract}

Key words: global, nursing research, doctorate in nursing, Africa, Rwanda

\section{Introduction}

This paper was delivered as a keynote address at the January 2015 Global Conference organized by the School of Nursing and Midwifery, College of Medicine and Health Sciences, University of Rwanda and provides a global overview of the status of nursing research. Many countries around the world are trying to understand how investments in research can advance health systems to improve health outcomes and address health inequities. A critical component of health research is nursing research, and internationally there is an increased focus on evidence to demonstrate that the expenditure on research is making a difference. However, in observing the status of nursing research globally, it seems that building nursing research capacity in low and middle income countries (LMICs) remains a challenge. This paper will provide a snapshot of research production globally in terms of scientific research, innovation, and publications. It will continue to investigate the challenges that nursing researchers face and will conclude with possible solutions.

\section{Global status}

Notwithstanding years of investment in research in LMICs, slow progress is visible when studying the status of research around the world. Furthermore, of concern is the absence of up to date information when comparing the developed world with the developing world in terms of knowledge production. Worldmapper (www.worldmapper.org) is an interesting internet application that shifts the images of the world based on the data available per continent and region. When scientific research output in the form of scientific papers is examined, researchers in the United States published three times more scientific papers than Japan, which has the second highest publication population. More scientific research and publication of results came from developed countries that have richer territories. Scientific papers covered physics, biology, chemistry, mathematics, clinical medicine, biomedical research, engineering, technology, and earth and space sciences. To view this map, please use the following hyperlink (http://www. worldmapper.org/posters/worldmapper_map205_ ver5.pdf).

The concern in terms of research development in LMICs remains valid, especially in Africa. In order to increase research output, investments are needed. Globally between $0 \%$ and $4 \%$ of the GDP of countries' expenditure is allocated to research (World Bank, 2015). The countries investing the most are Sweden (2012 at 3.41\%), Japan (2012 at 3.39\%) and Finland (2015 at 3.55\%) down from $3.90 \%$ in 2010. Interesting to note is that not all high income countries continuously increase their investment, for

*Corresponding author: Klopperhc@gmail.com 
example Canada has cut investment from $1.86 \%$ in 2010 to $1.73 \%$. However no clear trend is observable among the LMICs and BRICS (Brazil, Russia, India, China, and South Africa) - some countries are increasing the investment (e.g. Argentina, China, India, Botswana) and others are decreasing (e.g. Burundi, Mexico, Colombia). Rwanda's investment in education and research is mainly to obtain graduate de- grees. Hence, investment towards research capacity building is urgently needed in Rwanda.

Figure 1 shows annual research and development spending, indicating the rise of the BRICS countries (Brazil, Russia, India, China and South Africa) (OECD, 2012).

\section{WORLD OF RESEARCH AND DEVELOPMENT}

Size of circle reflects the relative amount of annual R\&D spending (in 2005 US\$ constant prices and PPP)

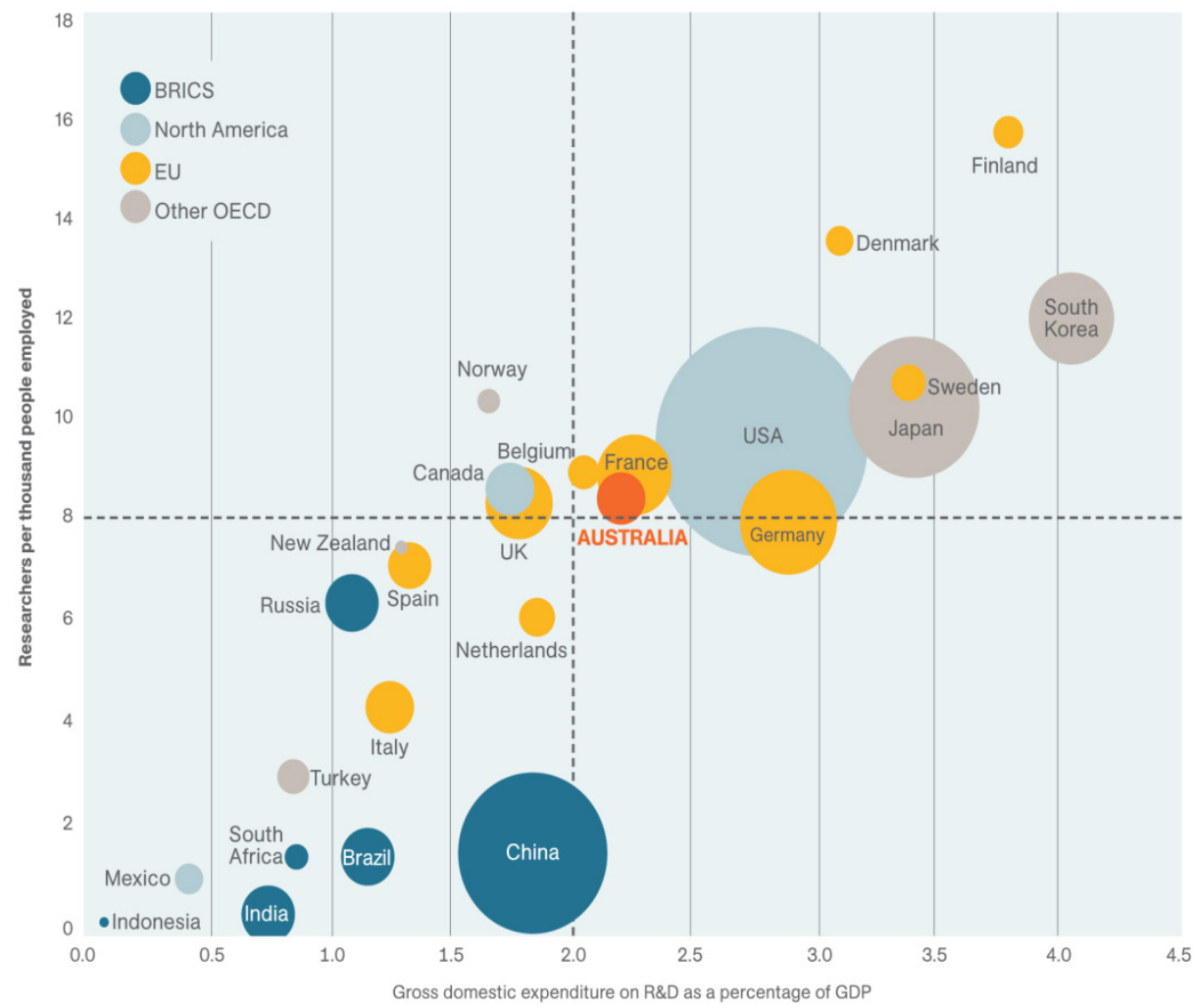

Source: OECD, Main Science and Technology Indicators Database, Brazil's Ministry of Science, Technology and Innovation and UNESCO Institute for Statistics, June 2013; Austrade

Figure 1. World of Research and Development (OECD, 2012; UNESCO, 2013)

The assumption would be that countries that invest in research and development would also have higher research outputs. Figure 2 published in Nature shows the top 40 countries in terms of publication outputs (Van Noorden, 2012). The United States of America (USA) remains the country with the highest numbers of publications globally, followed by China and then the United Kingdom. Only two African countries are in the top 40 countries that invest in research and development and these are Egypt and South Africa. From Figure 2 it is clear that the countries with the highest investment do not count amongst the highest producers. 


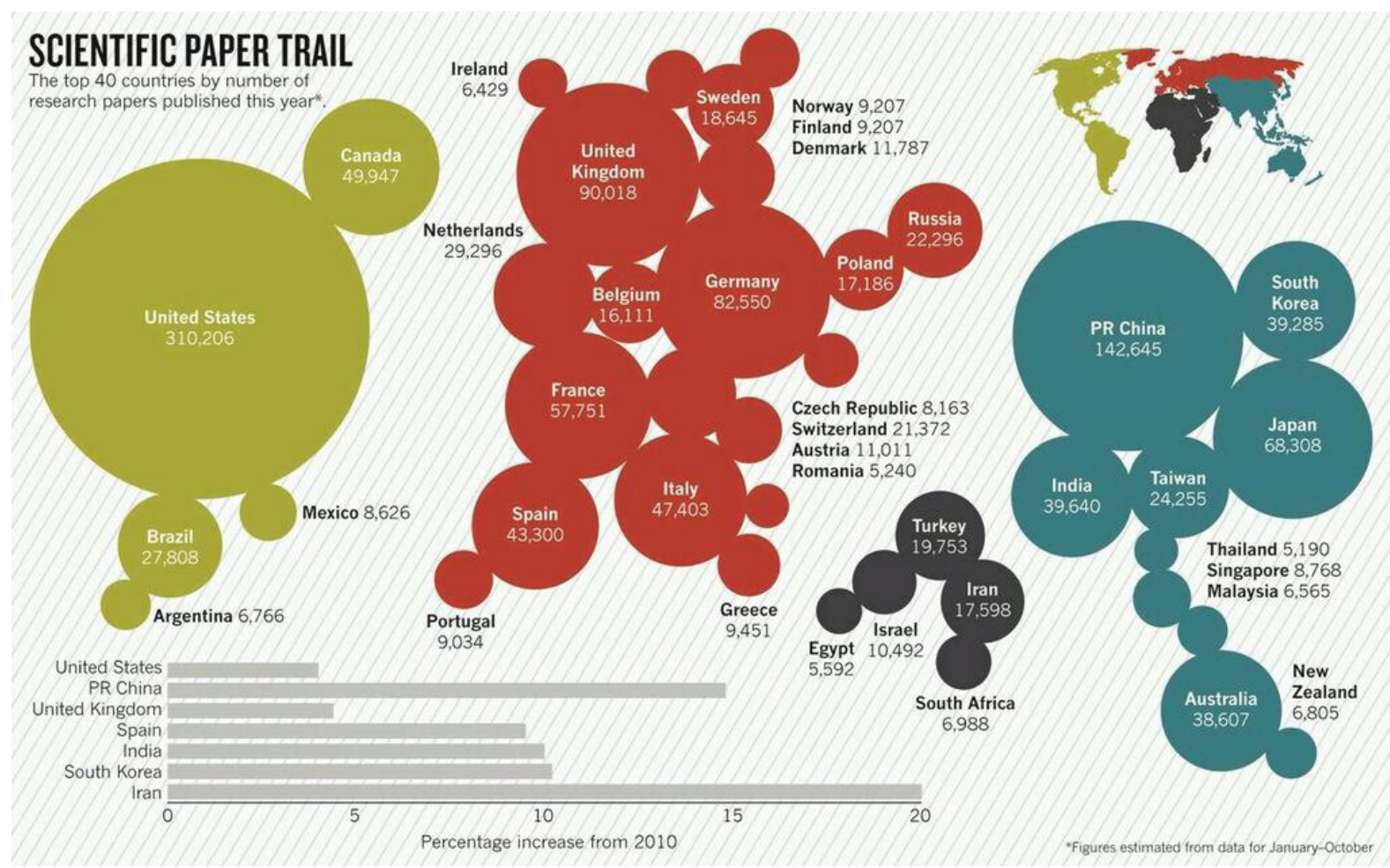

Figure 2. Scientific paper trial of the top 40 countries (Van Noorden, 2012)

Another measure of research production is the number of PhDs produced each year. Nature reported that there had been close to $40 \%$ growth globally in doctoral students graduating between 1998 and 2008 (MacGregor, 2013). Rapidly developing countries seem to graduate higher numbers of doctoral students at an output of more than $17 \%$ from Mexico and 40\% from China, with some 50,000 people graduating with doctorates across all disciplines in 2009. These numbers are impressive when compared to countries that already have high levels of doctoral production such as the United States, United Kingdom, and Germany with growth at around $5 \%$ or less. Africa needs to expand on the pool of doctorate holders in order to be able to compete globally.

South Africa's (SA) production of $\mathrm{PhDs}$ per million of the population compared poorly with other countries such as Portugal (569 per million), South Korea (172 per million), Brazil (42 per million) and Australia (264 per million) per annum. South Africa only produced $26 \mathrm{PhD}$ graduates yearly per million of the total population (inclusive of nursing) and is under performing in comparison to most other emerging economy countries (Jansen et al., 2010). There are about four $\mathrm{PhD}$ prepared nurses in Rwanda for a population of over a 10 million people (Mukamana
D., personal communication). This small number should not be compared with the numbers mentioned above as this relates to PhDs in Nursing only.

\section{Challenges and Trends impacting on Nurs- ing Research}

There are many trends that will influence nursing research, education, and practice over the next decade. However, only four will be discussed here: technology, workforce issues, interprofessional education and practice, and the need for more $\mathrm{PhD}$ prepared nurses.

\section{Technology}

Data shows that by the end of 2014, almost 3 billion people around the globe were using the internet. Two-thirds of the users are from the developing world, showing a $26.5 \%$ penetration rate per annum from developing countries over the past fourteen years. In Africa the penetration rate is $26.5 \%$ - the lowest of all the regions of the world (Internet World Stats, 2015). The assumption is that Africa and other developing countries don't have regular access to the internet. However, we have seen a huge growth in the use of mobile technology among the African users. By the end of 2013, there were 526 million users in 
Africa and the Middle East. This number is projected to increase to 671 million by 2017 , showing that mobile technology has become part of everyday life in the developing world. Cellular phones are particularly popular. In South Africa $91 \%$ of the population owns a cell phone (the highest in Africa), and 43\% have indicated that they use it to access the internet occasionally. Since technology was identified as being a government priority in Rwanda, the government has provided fiber optics throughout the country, and cell phone availability is at $65 \%$, even in rural areas (Ministry of Youth \& ICT, 2014).

Reviewing other African countries has similar results. In Nigeria $78 \%$ of the population own cell phones, and $33 \%$ use these phones for internet access; in Kenya $82 \%$ of the population own cell phones and $37 \%$ use them for internet access (Pew Research Center, 2015). We are surpassing the stage where internet access was only available to the developed and established economies. With internet access becoming more accessible to the developing world, we will be able to use the technology to reach rural populations with health promotion programmes, to improve access to treatment through telemedicine, and provide access to continuous education programmes for health care professionals. Nurses of the $21^{\text {st }}$ century need to be competent and skilled in the use of the computer and other technologies, as access to data and different means of communication and observations will have an impact on nursing research, education, and practice.

\section{Workforce}

Globally it is predicted we will have a health workforce crisis. More than 59 million health care professionals are at the core of health care delivery and health systems, with nurses accounting for $60 \%$ of the total global health workforce. Low and middle income countries face the most severe challenges in ensuring an adequate health care workforce. For example, Sub-Saharan Africa bears more than 24\% of the global burden of disease, but has access to only 3\% of the world's health care workers (Bhatt, Giri, \& Koirala, 2008). A recent analysis conducted by the Global Health Workforce Alliance and WHO estimated a gap of 7.2 million professional health workers in 2012, set to rise to 12.9 million over the next decades (WHO, 2014). In view of the fact that WHO intends to provide universal access to healthcare, a threshold has been set at 22.8 workers per
10,000 population. In mainly developed countries this threshold is met, but in countries such as Ethiopia a growth percentage of 1,354 workers will be required to meet this threshold.

Research over the past two decades indicates that nursing shortages have a negative impact on patient outcomes as a result of poor quality of care (Aiken, Clarke, Sloane, Sochalski, \& Silber, 2002; Aiken, Clarke, Cheung, Sloane, \& Silber, 2003; Sermeus et al., 2011; Klopper, Coetzee, Pretorius, \& Bester, 2012; Coetzee, Klopper, Ellis, \& Aiken, 2013). In Rwanda the health workforce shortage, especially a shortage of nurses, was aggravated by the genocide against the Tutsi in 1994, when most of the health professionals were either killed or fled the country (Roxburgh, Tayor, \& Murebwayire, 2009). Only 30\% of health facilities met the minimum staffing norms required and the country was among 57 countries with an important shortage of health workers (World Health Report, 2006). We have seen some interventions that have led to curtailing the shortage in the USA, which includes magnet hospitals ensuring the best quality of care with adequately trained staff, and the mandatory staffing ratios in California. It is based on the Institute of Medicine's (IOM) report (2010) which recommended that nurses achieve higher levels of education and training through an improved educational system that promotes seamless academic progression. The target of $80 \%$ of nurses to be prepared as a baccalaureate-degree in the USA by 2020 has been set. Along this line, Rwanda has been striving to achieve a high number of qualified and competent nursing staff, aiming to increase the number from 8,513 to 11,384 by 2018 (Binagwaho et al., 2013).

However, the challenges in Africa remain huge. Some of the challenges include poor working environments, under-resourced facilities, and limited resources for training and development. These challenges result in low levels of degree trained nurses, lack of leadership competencies, nurses having limited influence on policy, and nurses' intentions to leave the profession are linked to low levels of job satisfaction. Career advancement remains challenging in Rwanda. Nurses' salaries are determined by the level of education and yet opportunities for graduate studies in nursing are limited. This has led many nurses to undertake graduate studies in other disciplines, resulting in limited availability of nursing scholars to teach nursing science (Uwayezu, 2006). In many countries 
however, the challenges are not just organizational in nature, but linked to issues such as higher demands on the health system due to a growing middle class, or high unemployment. This situation provides vast opportunities for research, including creative and innovative interventions to improve staff and patient outcomes, and flexible alternative educational delivery models.

\section{Interprofessional education and practice}

We have seen over the past decade that WHO has moved towards actions and strategies that may alleviate some of the strain on the healthcare system and mitigate the global health workforce crisis, for example: task shifting, interprofessional education, and collaborative practice. The Institute of Medicine in 2001 and more recently the WHO (2010) recommended that professional teams working together can best address the complex health needs of the population. Interprofessional education is critical to prepare health care professionals for collaborative practice-ready responses to health needs as they occur. Collaborative practice occurs when health care professionals from different professional backgrounds work together to deliver the best possible care to patients, families and communities. Interprofessional collaborative practice has been defined as a process which includes communication and decision-making, enabling a synergistic influence of grouped knowledge and skills and includes the elements of responsibility, accountability, coordination, communication, cooperation, assertiveness, autonomy, and mutual trust and respect (Kaperski, 2000; Interprofessional Education Collaborative Expert Panel, 2011). Nurses should be full partners, with physicians and other health care professionals, in redesigning health care and to strengthen health systems. In 2010, the WHO developed a Framework for Action on Interprofessional Education and Collaborative Practice

Providing a range of mechanisms on how interprofessional education and collaborative practice should be utilized to strengthen health care systems.

\section{Need for more $\mathrm{PhD}$ prepared nurses}

We have seen a rapid increase in the number of doctoral nursing programs in the world from 286 in 2005 to 333 in 2012 (International Network for Doctoral Education in Nursing (INDEN), 2012). McKenna (2013) stated that in 1980 of the 1.5 million registered nurses (RN) in the USA, 1,650 were doctoral prepared (less than $0.2 \%$ ). In 2009, we have seen 15,398 doctoral prepared nurses from the total of 2.4 million RNs. According to INDEN in 2012, 370 nursing doctoral programs were offered across 34 countries. In the USA there are $243 \mathrm{PhD}$ programs approved with an additional 145 in development (American Association of Colleges of Nursing, 2014). In the United Kingdom 80 university nursing departments are offering PhD training (McKenna, 2013), but in Africa the progress is slow and we continue to see a limited number of $\mathrm{PhD}$ programmes in nursing. Only five countries in Africa are offering PhDs in Nursing, South Africa, Namibia, Nigeria, Egypt (with seven programmes), and Kenya, with Malawi offering an Interprofessional $\mathrm{PhD}$. In South Africa, 16 universities are offering $\mathrm{PhD}$ programmes in nursing - the highest number in Africa (INDEN, 2012). Rwanda is yet to develop a $\mathrm{PhD}$ programme in nursing, but eight master's degree programs in nursing are in the approval process and will represent a starting point on which $\mathrm{PhD}$ programs can be developed.

So why do we need more nurses trained to the doctorate level? There is a critical need for more doctorate prepared nurses in order to advance the science of nursing and nursing education; to educate future generations of nurses so they are well prepared as a workforce, to lead change, and to design health systems that are implementable, efficient and cost-effective. New knowledge is generated through research, and $\mathrm{PhD}$ prepared nurse scientists are at the forefront of developing the science of nursing. To generate a new body of knowledge in nursing is to provide evidence of how to improve the quality of care of patients, families, and communities. In order to lead change, doctoral students need to recognise their role as leaders and the important role they play in practice, and their needed contribution to the scholarship of discovery.

Although the number of nursing doctoral programs has increased, it seems that the total enrolment of students in these programs has remained fairly constant. This has given rise to the problem that such low numbers of faculty members have doctorates, where doctoral preparedness is essential. Approximately $50 \%$ of nursing faculty in the USA have a doctoral degree which is among the highest globally (AACN, 2014). This is also a group of nursing faculty where we see high rates of retirement, adding to the void in faculty numbers that already exists.

As we see the push to increase doctorate prepared 
nurses, a prominent question remains - should this be $\mathrm{PhD}$ or Doctorate in Nursing (DNP)? The focus of this paper is not to answer this question, but the literature clearly indicates that there is a place for both in nursing academics. According to the American Association of Colleges of Nursing (AACN) (2014), the DNP is "designed for nurses seeking a terminal degree in nursing practice and offers an alternative to research-focused doctoral programs. DNP prepared nurses are well-equipped to fully implement the science developed by nurse researchers prepared in $\mathrm{PhD}$, Doctorate in Nursing Science (DNSc), and other research-focused nursing doctorates." The increase of Doctorate in Nursing graduates in the USA seems to be important to meet the demands of delivery of safe care. However, a word of caution to the developing countries (especially in Africa), is not just to follow this model without thoroughly investigating the consequences of the model, as career structures such as career ladder and salaries do not exist to accommodate the DNP prepared nurse in the African workforce. On the other hand, we still need more $\mathrm{PhD}$ prepared nurses to fill the gaps of research that exist in Africa and build a strong generation of nurse faculty.

\section{Considerations for the future}

Within the African context the following considerations and/or recommendations could be further explored to build nursing research capacity.

1. The number of doctoral programmes preparing nurses as scientists needs to be increased. More countries need to implement these programmes as it will allow for countries to increase the numbers and prepare and retain $\mathrm{PhD}$ prepared nurses within a country.

2. Clinical research should be the priority for nursing researchers in Africa. We see many studies addressing issues in administration and education, but very few clinical studies or those focusing on the improvement of practice are seen.

3. A model for interprofessional education and collaborative practice needs to be developed for Africa to address the high level of burden of disease seen in rural areas, as well as affect influence on the health systems. This may imply a need for the development of interprofessional or transdisciplinary doctoral programmes.

4. Recruitment of younger doctoral candidates is pivotal. The average age of a $\mathrm{PhD}$ student that completes studies in South Africa is around 52 years of age - one could infer that this would also be the norm for the rest of Africa.

5. Creating research and supported funding opportunities for post-doctoral nursing candidates should be a priority. This will ensure retention of nurse researchers and building additional capacity to lead research programmes.

6. Investment in nursing research infrastructure is needed. Money allocated by African governments is limited for nursing research, and the increase of these funds will make it possible to develop and implement quality research.

7. To overcome the shortage of experienced research supervisors, panel supervision may be considered. This will allow for the novice supervisor to learn from experienced supervisors while being involved in $\mathrm{PhD}$ supervision.

8. African countries need to develop relationships among themselves through establishment of South-South relationships. One way of ensuring these exchanges of expertise is to build a network of nursing professors in Africa to collaborate in conducting research, teaching in $\mathrm{PhD}$ programmes and supervision of $\mathrm{PhD}$ students.

9. Use of technology must be expanded to allow for exchanges and creative and novel ways to work together.

10. Access to health care in Africa will be possible if nurse-lead care is the norm. An investigation should be conducted to establish the applicability of the DNP model to Africa, to prepare nurses for the advanced practitioner role. This will also allow for opportunities to renew the curricula in the $\mathrm{PhD}$ programmes.

\section{Conclusion}

This paper highlighted some of the challenges and trends impacting the nursing profession globally. Emphasised were the changing technology practices, the shrinking nursing workforce, the need for inter- 
professional education and practice, the influence of research on changing practice and policy, and the importance of increasing the number of nurses educated as a doctorate level. In lower and middle income countries, and particularly in Rwanda, these challenges are prominent for the nursing profession.

Nurses play a pivotal role in the healthcare systems and can be the champions for improving health system efficacy, efficiency, and ultimately patient outcomes. Education and research at the nursing doctorate level have been identified as being essential to the advancement of healthcare through the development and dissemination of new knowledge and the promotion of evidence-based practice. Research findings provide nurses with accurate tools and opportunities to ensure optimal patient care and improved health care systems.

The lower and middle income countries require innovative solutions to advance healthcare. Research evidence shows that the use of technology, interprofessional collaboration, mutual relationships among countries, as well as increased investment in research does build a stronger infrastructure and increases health care delivery in a resource poor environment. The nursing profession's contributions to health care can be accelerated through education and practice by nurses pursuing doctorate and post-doctoral degrees which will offer opportunities for nurses to engage in innovation, discovery, and participate as a partner in policy development and leadership.

\section{References}

Aiken, L.H., Clarke, S.P., Sloane, D.M., Sochalski, J., \& Silber, J.H. (2002).

Hospital nurse staffing and patient mortality, nurse burnout, and job dissatisfaction. The Journal of the American Medical Association, 288, 1987- 1993.

Aiken, L.H., Clarke, S.P., Cheung, R.B., Sloane, D.M., \& Silber, J.H. (2003). Educational levels of hospital nurses and surgical patient mortality. The Journal of the American Medical Association, 290, 1617-1623.

American Association of Colleges of Nursing (AACN). (2014). DNP fact sheet. Washington, DC: AACN. Retrieved from http://www.aacn.nche.edu/media-relations/fact-sheets/dnp.

Bhatt, V., Giri, S., \& Koirala, S. (2008). Health workforce shortage: A global crisis. The Internet Journal of World Health and Societal Politics, 7(1). https://ispub.com/ IJWH/7/1/6202.

Binagwaho, A., Kyamanywa, P., Farmer, P. E., Nuthulaganti, T., Umbyeyi, B., Nyemazi, J. P., Mugeni, S. D., Asimwe, A., Ndagijmana, U., Lamphere
McPherson, H., Ngirabega, J. D., Siney, A., Uwayezu, A., Wagner, C.M., Nutt, C.T., Eldon-Edington, M., Cancedda, C., Magaziner, I. C., \& Goosby, E.

(2013). The Human Resources for Health Program in Rwanda - A new partnership. The New England Journal of Medicine, 369(21), 2054-2059.

Coetzee, S.K., Klopper, H.C., Ellis, S.M., \& Aiken, L.H. (2013). A tale of two systems - Nurses practice environment, well-being, perceived quality of care and patient safety in private and public hospitals in South Africa: A questionnaire survey. International Journal of Nursing Studies, 50(2), 162-173.

Institute of Medicine (IOM). (2010). The future of nursing: Leading change, advancing health. Retrieved from http: / / www.iom.edu/Reports/2010/The-Future-ofNursing- Leading-Change-Advancing-Health.aspx.

International Network for Doctoral Education in Nursing (INDEN) (2012). Databases of accredited doctoral programs in 34 countries. John Hopkins University, Balitimore, MD. Retrieved from http://nursing.jhu. edu/excellence/inden/.

Internet World Stats. (2015). Internet world stats - Usage and population stats - Africa. Retrieved from http:// www.internetworldstats.com/africa.htm.

Interprofessional Education Collaborative Expert Panel. (2011). Core competencies for interprofessional collaborative practice: Report of an expert panel. Interprofessional Education Collaborative. Washington, D.C.: Author. Retrieved from http://www.aacn.nche.edu/education-resources/ipecreport.pdf

Jansen, J., Bawa, A., Buhlungu, S., Harman, K., Mouton, J., Nerad, M., Reddy, P., Samual, M., \& Triegaardt, D. (2010). The PhD study. An evidenced-based study on how to meet the demands for high-level skills in an emerging economy. Consensus report. Pretoria: Academy of Science of South Africa. Retrieved from http://www.assaf.co.za/wp-content/uploads/2010/10/40696-Boldesign-PHD-small-optimised.pdf.

Kasperski, M. (2000). Implementation strategies: 'Collaboration in primary care - family doctors and nurse practitioners delivering shared care'. Retrieved from http:// www.cfpc.ca/English/CFPC/CLFM/bibnursing/default.asp?s=1

Klopper, H.C., Coetzee, S.K., Pretorius, R., \& Bester, P. (2012). Practice environment, job satisfaction and burnout of critical care nurses in South Africa. Journal of Nursing Management, 20(5), 685-95. doi: 10.1111/j.13652834.2011.01350.x.

MacGregor, K. (2013). Understanding the demands of PhD production. University World News, 300.

Retrieved from http://www.universityworldnews.com/ article.php?story $=20131215083250788$.

McKenna, H. (2013, July). Quality of doctoral education across seven countries. Presentation at INDEN conference, Prague. 
Ministry of Youth and ICT. (2014, June). Rwanda ICT sector profile 2013. Towards a Cashless Economy. Retrieved from http://www.myict.gov.rw/fileadmin/ Documents/ICT_Sector_Profile_2013/ICT_Sector_ Profile_for_Web_copy.pdf

Organisation for Economic Co-operation and Development (OECD). (2012). Retrieved from http://www. oecd.org/newsroom/china-headed-to-overtake-euus-in science-technology-spending.htm. Pew Research Center. (2015). Global attitudes \& trends. Retrieved from www.pewglobal.org.

Roxburgh, M., Tayor, J., \& Murebwayire, M. (2009). Rwanda: A thousand hills, a thousand dreams, a thousand challenges for nurses and midwives and the Millennium Development Goals. Nurse education in practice, 9, 349350 .

Sermeus, W., Aiken, L.H., Van den Heede, K., Rafferty, M. A., Griffiths, P., Moreno-Casbas, M., Busse, R., Lindqvist, R., Scott, A., Bruyneel, L., Brzostek, T., Kinnunen. J., Schubert, M., Schoonhoven, L., Zikos, D. \& RN4CAST consortium. (2011). BMC Nursing, 10(6),1472-6955.

United Nations Educational, Scientific and Cultural Organization. 2013. UNESCO Institute for Statistics. Retrived from http://www.uis.unesco.org/Science'Technology/Pages/research-and-development-statistics. aspx. Accessed 18 May 2015.
Uwayezu, A. (2006). Exploring the reasons Rwandan nurses change employment status. Master's thesis, University of KwaZulu Natal. Durban, South Africa. Van Noorden, R. (2012). 365 days: 2011 in review. Nature, 2229(480), 426-427. doi: 10.1038/480426a.

World Health Report. (2006). Working together for health. Geneva: World Health. Organization. Retrieved from http://www.who.int/whr/2006/whr06_en.pdf.

World Health Organization (WHO). (2010). Framework for action on interprofessional education and collaborative practice. Geneva: WHO retrieved from http://whqlibdoc.who.int/hq/2010/WHO_HRH_HPN_10.3_ eng.pdf

World Health Organization (WHO). (2014). Health workforce 2030. A global strategy on human resources for health. Federal office of Public Health, Switzerland: WHO. Retrieved from http://www.who.int/workforcealliance/knowledge/resources/strategy

World Bank. (2015). Research and development expenditure (\% of GDP). Retrieved from http://data.worldbank.org/indicator/GB.XPD.RSDV.GD.ZS

The new World mapper. (2015). World mapper - the world as you've never seen it before. Retrieved from www. worldmapper.org. 